OSF Preprints

Jurnal of Management View

\title{
STRATEGIES FOR IMPROVING MARKETING PERFORMANCE WITH RED OCEAN THEORY
}

\author{
Bun Norikun \\ Program Pascasarjana Magister Manajemen Fakultas Ekonomi dan Bisnis \\ Universitas Muria Kudus \\ Mokhamad Arwani \\ Mamik Indaryani \\ Fakultas Ekonomi dan Bisnis Universitas Muria Kudus
}

\begin{abstract}
This research analyzes the work of marketing in Convection Business in Kudus Disctrict, particularly in the competitiveness of its Micro, Small and Medium business (UKM). UKM does serve an important role in economy development, since it provides job opportunities, as well as opens new field of jobs. It is particularly true in Convection Business UKM, because it has a very competitive market or red ocean (already existed in the market). This research tries to analyze how various strategy variables, which are innovation abilities, market orientation, and entrepreneurship orientation through competitive advantage can significatly improve marketing performance in Convection Business in Kudus District. The research collects the samples from 194 Convection business users in Kudus District. This research bases its analysis using Structural Equation Modelling (SEM). It gets a conclusion that innovation abilities, market orientation, entrepreneurship orientation and competitive advantage do give direct contribution toward marketing performance, while innovation abilities, market orientation and entrepreneurship orientation through competitive advantage do give indirect contribution toward marketing performance.
\end{abstract}

Keywords: innovation abilitiy, market orientation, entrepreneurship orientation, competitive advantage, and marketing performance.

Abstrak : Penelitian ini meneliti tentang kinerja pemasaran melalui keunggulan bersaing Usaha Kecil dan Menengah (UKM) Kerajinan Konveksi Kabupaten Kudus. UKM memainkan peran penting dalam pengembangan ekonomi karena dari usaha mikro dan kecil yang menyediakan lapangan kerja dan menciptakan lapangan kerja baru, terutama pada UKM Kerajinan Konveksi di Kabupaten Kudus merupakan bisnis usaha yang memiliki pemasaran kompetitif atau red ocean (pasar yang sudah ada). Peneliti mencoba untuk menganalisis strategi meningkatkan kinerja pemasaran dengan variabel kemampuan inovasi, orientasi pasar, dan orientasi kewirausahaan terhadap kinerja pemasaran melalui keunggulan bersaing pada kerajinan konveksi di Kabupaten Kudus. Sampel pada penelitian ini sebanyak 194 wirausaha kerajinan konveksi Kabupaten Kudus. Teknik analisis yang dipergunakan adalah Structural Equation Modelling (SEM). Kesimpulan yang dapat diambil dalam penelitian ini adalah kemampuan inovasi, orientasi pasar, orientasi kewirausahaan, dan keunggulan bersaing mempunyai pengaruh langsung terhadap kinerja pemasaran, sedangkan kemampuan inovasi, orientasi pasar, orientasi kewirausahaan mempunyai pengaruh tidak langsung terhadap kinerja pemasaran melalui keunggulan bersaing.

Kata kunci : kemampuan inovasi, orientasi pasar, orientasi kewirausahaan, keunggulan bersaing, dan kinerja pemasaran.

Usaha Kecil dan Menengah (UKM) merupakan salah satu bagian penting bagi perekonomian suatu bangsa, begitu juga bagi perekonomian Indonesia. Ukuran UKM juga masih mengandung kekurangan atau kelemahan yang membuat pengelola mengalami kesulitan dalam menjalankan usaha atau tugasnya yaitu 1). Kesulitan pemasaran. 2). Keterbatasan financial. 3). Keterbatasan Sumber daya Manusia (SDM). 4). Keterbatasan Bahan baku. 5). Keterbatasan teknologi. Penelitian Sukirman dan Indaryani
(2014) juga mengungkapkan usaha kecil sedang menghadapi masalah, diantaranya organisasi lemah, pemasaran sulit, tempat usaha sempit, sarana kurang memadai, modal usaha kecil, jiwa kewirausahaan rendah, kurangnya memperhatikan lingkungan dan pelayanan kurang baik.

Selain kelamahan yang dimiliki UKM, mereka memiliki fleksibilitas yang tinggi, UKM memiliki berbagai kelebihan, terutama dalam segi pembentukan dan operasional yaitu: 1). Inovasi dalam teknologi mudah dilakukan dalam upaya 
pengembangan produk. 2). Pemerataan penduduk atau berbasis pada sumber daya local dalam memanfaatkan potensi secara maksimal dan memperkuat kemandirian. 3). Kemampuan menciptakan kesempatan kerja yang cukup banyak atau penyerapan tenaga kerja cukup tinggi. 4). Memiliki fleksibilitas dan kemampuan menyesuaikan diri terhadap kondisi pasar yang berubah dengan cepat dibandingkan dengan perusahaan berskala besar yang pada umumnya birokratis. 5). Terdapat dinamisme manajerial dan peranan kewirausahaan. 6). Jumlah dan perannya di Negara berkembang sehingga merupakan alat pemerataan pembangunan yang efektif (Hafni dan Rozali, 2016).

Disisi local, Kabupaten Kudus terkenal sebagai kota kretek dan juga terkenal dengan kota industri. Hal ini dikarenakan banyaknya jumlah UKM yang ada dan UKM di Kabupeten Kudus memiliki peran penting dan strategis. Kabupaten Kudus mempunyai dasar semangat untuk memperkuat kewirausahaan menggunakan filosofi Gusjigang yaitu sebagai etos kerja dan perilaku ekonomi dagang masyarakat Kabupaten Kudus. Gusjigang mempunyai persepsi sebagai citra diri masyarakat Kudus yang memiliki karakter bagus dalam berperilaku, ngaji (belajar), dan pintar berdagang.

Usaha kerajinan konveksi di Kabupaten Kudus terdapat perbedaan karakteristik dalam menjalankan usaha dengan pemasaran produknya. Sementara itu menyebabkan adanya dua paradigma yaitu vertikal dan horisontal (new wave marketing). Paradigma vertikal merupakan cara berorientasi pada pasar lama, hal ini usaha kerajinan konveksi hanya melakukan produksi berdasarkan pemesanan dari pelanggan saja. Sedangkan paradigma horizontal (new wave marketing) merupakan cara berorientasi pada pasar baru, hal ini new wave/marketing melakukan tiga buah sub-culture yaitu youth (merangkul kalangan muda), anak muda atau kelompok remaja dalam Arwani (2011), menghabiskan sebagian besar uangnya pada produk pakaian, perhiasan, dan produk/jasa kecantikan, women (merangkul kalangan wanita yang sensitive dan peduli terhadap temen dan keluarganya), Netizen (pengguna internet).

\section{TELAAH PUSTAKA}

\section{Strategi Red Ocean}

Strategi merupakan sarana organisasi yang digunakan untuk mencapai tujuannya. Strategi menerapkan konsep manajemen dari lingkungan bisnis, misi-visi, dan tujuan (Crevens, 2015).
Bentuk pasar yang paling umum saat ini yang menjadi persaingan yang kompetitif yaitu red ocean karena merupakan persaingan pasar yang berdarah-darah atau perebutan pasar yang telah ada. Tujuan dari perebutan pasar adalah untuk mendapatkan pangsa pasar yang lebih besar. Sementara Kim dan Mouborgne, (2011) juga menyatakan bahwa Red ocean strategy atau starategi samudra merah merupakan dimana kondisi persaingan saat kompetitif atau matimatian sampai titik darah penghabisan yang berdasarkan perebutan pasar. Hal ini red ocean adalah situasi persaingan dalam semua pasar yang relevan saat ini. Aturan persaingan menunjukkan bahwa ada dua acara untuk mencapai keunggulan bersaing (Georgopoulos 2011) yaitu 1). Perusahaan dapat mengikuti strategi kepemimpinan biaya (menyediakan produk dengan harga terendah di pasar), 2). menetapkan strategi diferensiasi produk (dengan meyakinkan konsumen bahwa produknya lebih baik atau berbeda dari yang lain di pasar).

\section{Kemampuan Inovasi}

Kemampuan inovasi adalah suatu proses dalam kemampuan organisasi yang menimbulkan ide-ide baru untuk menciptakan keberhasilan produk baru dengan perkembangan proses produksi yang berdampak pada peningkatan penjualan, keuntungan, dan kekuatan persaingan. Sedangkan menurut Sulistyo, dkk (2016) kemampuan inovasi didefinisikan sebagai suatu proses yang dimulai dengan sebuah ide, temuan hasil pengembangan dan pengenalan produk baru, proses dan layanan baru di pasar.

\section{Orientasi Pasar}

Orientasi pasar merupakan suatu strategi perusahaan dalam memberikan nilai bagi pelanggan, pelayanan pelanggan atau memuaskan pelanggan yang unggul dengan terus menerus. Zehir, et al, (2015) orientasi pasar merupakan suatu strategi perusahaan untuk melakukan perbaikan diri dengan cara menjawab kebutuhan pasar dan meramalkan kondisi yang akan terjadi pada pasar yang dapat menghasilkan keuntungan di atas keunggulan kompetitif rata-rata dan jangka panja.

Slater dan Narver (1994) dalam Han, Jin K. et al., (1998) menyatakan orientasi pasar merupakan sebagian dari budaya perusahaan dengan memberikan nilai bagi pelanggan dengan terus-menerus. Narver dan Slater (1990), menyatakan orientasi pasar memiliki tiga komponen yaitu orientasi pelanggan, orientasi 
pesaing, dan koordinasi interfungsional yang masing-masing bergerak dalam generasi intelijen, penyebaran, dan tanggapan terhadap informasi yang di kumpulkan.

\section{Orientasi Kewirausahaan}

Kewirausahaan adalah kemampuan dalam berpikir kreatif dan bertindak inovatif sebagai dasar, sumber daya, tenaga penggerak, dan proses untuk menghadapi tantangan gaya hidup di pasaran. Zimmerer dan Scarborough (2005) dalam Sukirman (2014) memberikan konsep wirausaha merupakan seseorang yang menghadapi resiko dimasa mendatang dan bertumbuh untuk mendapatkan profit dengan menggunakan seluruh sumber daya yang dimiliki sehingga mengalami peningkatan terhadap usaha.

Seseorang yang memiliki kewirausahaan bukanlah pembawaan atau keturunan dari keluarga, tetapi kewirausahaan salah satunya dapat diukur melalui keahlian yang dapat dipelajari (Handayani dan Suyanto, 2016).

\section{Keunggulan Bersaing}

Keunggulan bersaing adalah keunggulan melebihi pesaing yang diperoleh dengan menawarkan nilai yang lebih besar kepada konsumen daripada tawaran pesaing (Kotler \& Amstrong, 2008). Norikun dan Kuswardani (2015) menyatakan bahwa keunggulan produk merupakan suatu yang terlihat menarik dari produk lain, lebih tinggi spesifikasi, serta dapat memuaskan konsumen. Jadi keunggulan bersaing merupakan keunggulan yang telah diciptakan oleh perusahaan dengan menawarkan nilai kepada pelanggan yang unggul daripada pesaing.

Porter dalam David (2008), mendukung adanya keunggulan bersaing atau strategi genetic terdapat tiga dasar: Cost leadership, Differentiation, Focus. Arwani (2012), keunggulan bersaing yang dapat menciptakan pencapaian tujuan perusahaan dengan berfokus pada marketing mix yang akan mempengaruhi keputusan konsumen dikenal dengan $4 \mathrm{P}$ yang terdiri dari produk, harga, promosi, dan distribusi.

\section{Kinerja Pemasaran}

Kinerja pemasaran adalah suatu ukuran atau standar hasil pemasaran yang telah ditetapkan oleh perusahaan untuk meningkatkan prestasi pemasaran dalam suatu perusahaan atau organisasi. Ferdinand (2013) menyatakan bahwa kinerja pemasaran merupakan konsep untuk mengukur prestasi pemasaran suatu produk.
Kinerja pemasaran merupakan pencapaian yang diperoleh perusahaan dari kegiatan pemasaran yang telah dilakukan dan pemasaran dapat diukur melalui perspektif pelanggan, yaitu kepuasan pelanggan, profitabilitas pelanggan, dan perolehan pelanggan baru (Nandan dan Syahril, 2016). Monon et al,. (1996) dalam Widodo (2008) mengungkapkan mengukur kinerja pemasaran melalui pangsa pasar (market share), dan tingkat pertumbuhan penjualan (sales growth rate).

\section{Kerangka Konsep Penelitian}

Gambar 1 Kerangka Konsep Pemikiran

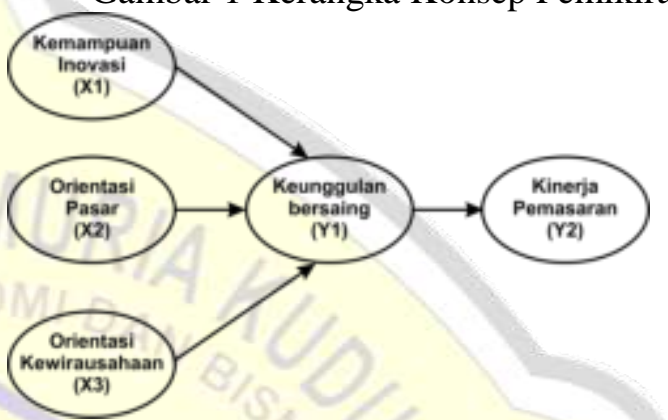

Sumber: Diolah dari kajian teori dan Empirik

Pernyataan Hipotesis

$\mathrm{H}_{1} \quad$ :Kemampuan inovasi berpengaruh signifikan terhadap keunggulan bersaing.

$\mathrm{H}_{2}$ :Orientasi pasar berpengaruh signifikan terhadap keunggulan bersaing.

$\mathrm{H}_{3}$ :Orientasi kewirausahaan berpengaruh signifikan terhadap keunggulan bersaing.

$\mathrm{H}_{4}$ :Kemampuan inovasi berpengaruh signifikan terhadap kinerja pemasaran.

$\mathrm{H}_{5}$ :Orientasi kewirausahaan berpengaruh signifikan terhadap kinerja pemasaran.

$\mathrm{H}_{6}$ :Orientasi pemasaran berpengaruh signifikan terhadap kinerja pemasaran.

$\mathrm{H}_{7}$ :Keunggulan bersaing berpengaruh signifikan terhadap kinerja pemasaran.

$\mathrm{H}_{8}$ :Kemampuan inovasi berpengaruh signifikan terhadap kinerja pemasaran melalui keunggulan bersaing.

$\mathrm{H}_{9}$ :Orientasi pasar berpengaruh signifikan terhadap kinerja pemasaran melalui keunggulan bersaing.

$\mathrm{H}_{10}$ :Orientasi kewirausahaan berpengaruh signifikan terhadap kinerja pemasaran melalui keunggulan bersaing.

\section{METODE PENELITIAN \\ Populasi dan Sampel Penelitian}

Populasi dalam penelitian ini adalah seluruh UKM pada kerajinan konveksi Dimana UKM konveksi merupakan usaha yang memiliki persaingan kompetitif pada pasar dalam 
merebutkan pelanggan yang tersebar di Sembilan kecamatan yaitu Kaliwungu, Kota, Jati, Undaan, Mejobo, Jekulo, Bae, Gebog, dan Dawe dengan kriteria UKM berdasarkan UU Nomor. 20 tahun 2008 sebanyak 808 UKM Kerajinan Konveksi di Kabupaten Kudus.

Tiknik pengambilan sampel ini menggunakan jenis purposive sampling. Pertimbangan yang dipakai dalam menentukan sampel penelitian ini adalah :

1. Responden memiliki UKM Kerajinan Konveksi dengan kekayaan bersih atau modal lebih dari Rp. 50.000.000 (lima puluh juta rupiah) tidak termasuk tanah dan bangunan tempat usaha.

2. Responden adalah UKM Kerajinan Konveksi menjalankan usaha minimal 3 tahun.

Pengambilan sampel menggunakan Slovin di dapat sebanyak 194 responden. Adapun jumlah sampel berdasarkan teknik proportionate stratified random sampling setiap kecamatan :

Tabel 1 Proportionate Stratified Random

Sampling UKM Kerajinan Konveksi Setiap Kecamatan Kabupaten Kudus:

\begin{tabular}{|l|c|c|}
\hline Kecamatan & $\begin{array}{c}\text { Populasi modal } \\
\mathbf{> 5 0 j u t a}\end{array}$ & $\begin{array}{c}\text { Jumlah } \\
\text { Sampel }\end{array}$ \\
\hline Undaan & 27 & 14 \\
\hline Kota & 78 & 40 \\
\hline Bae & 13 & 7 \\
\hline Jekulo & 3 & 2 \\
\hline Gebog & 163 & 84 \\
\hline Kaliwungu & 27 & 14 \\
\hline Jati & 52 & 27 \\
\hline Dawe & 14 & 7 \\
\hline Mejobo & 1 & 1 \\
\hline Total & 378 & 194 \\
\hline
\end{tabular}

Sumber : Dinas perindustrian, koperasi dan Usaha Kecil dan Menengah Kabupaten Kudus, 2018 (Diolah)

\section{Metode Pengumpulan Data}

Teknik pengumpulan data menggunakan wawancara untuk mendapatkan data kualitatif, penyebaran kuesioner untuk mendapatkan data kuantitatif dan diproses dengan tujuan untuk menguji serta menganalisis pengaruh eksogen dan endogen, serta untuk memeriksa validitas dan reliabelitas. Pengujian ini menggunakan teknik analisis Structural Equation Model (SEM) dengan program Analysis of Momen Structure (AMOS) versi 24 (Ghozali, 2017).

Variabel dan indikator pada penelitian ini adalah (1). Kemampuan inovasi dengan indikator inovasi produk, inovasi proses, inovasi organisasi, inovasi pemasaran. (2). Orientasi pasar dengan indikator orientasi pelanggan, orientasi distribusi, orientasi pemasok, orientasi kalaborasi, koordinasi antar fungsi. (3). Orientasi kewirausahaan dengan indikator keahlian atau keterampilan. pengambilan resiko, flexible, proaktif atau keaktifan. (4). Keunggulan bersaing dengan indikator kualitas atau daya tahan, ciri khas, daya meniru, transferabilitas (kemampuan meniru), kecepatan pengiriman dan pelayanan, tingkat harga. (5). Kinerja pemasaran dengan indikator pertumbuhan pelanggan, pendapatan penjualan, pangsa pasar, loyalitas pelanggan.

\section{HASIL DAN PEMBAHASAN}

Meansurement Model (Confirmatory Factor Analysis)

a. Confirmatory Factor Analysis Konstruk Eksogen

Tabel 2 Regresi Weight Confirmatory Factor Analysis Konstruk Eksogen

\begin{tabular}{|l|l|c|c|c|}
\hline & & C.R. & P & $\begin{array}{c}\text { Loading } \\
\text { Factor }\end{array}$ \\
\hline OP2 & orientasi_pasar & & & 0.459 \\
\hline OP3 & orientasi_pasar & 4.789 & 0.000 & 0.551 \\
\hline OP4 & orientasi_pasar & 4.386 & 0.000 & 0.521 \\
\hline OP1 & orientasi_pasar & 4.721 & 0.000 & 0.601 \\
\hline OP5 & orientasi_pasar & 4.705 & 0.000 & 0.566 \\
\hline KI1 & kem_inovasi & & & 0.572 \\
\hline KI4 & kem_inovasi & 4.865 & 0.000 & 0.610 \\
\hline KI2 & kem_inovasi & 5.191 & 0.000 & 0.536 \\
\hline KI3 & kem_inovasi & 4.996 & 0.000 & 0.667 \\
\hline OK4 & orientasi_kew & & & 0.646 \\
\hline OK3 & orientasi_kew & 6.599 & 0.000 & 0.593 \\
\hline OK2 & orientasi_kew & 6.646 & 0.000 & 0.671 \\
\hline OK1 & orientasi_kew & 6.976 & 0.000 & 0.716 \\
\hline Sumber
\end{tabular}

Sumber Data: Data primer yang diolah, tahun 2018

Gambar 2 CFA Konstruk Eksogen

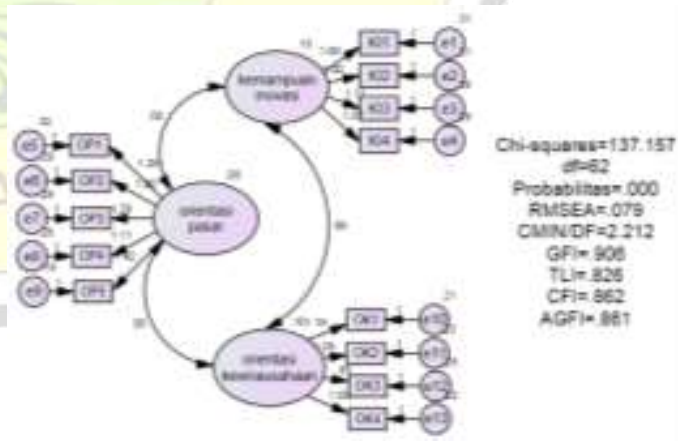

b. Confirmatory Factor Analysis (CFA) Konstruk Endogen

Tabel 3 Regresi Weight Confirmatory Factor Analysis Konstruk Endogen

\begin{tabular}{|l|l|c|c|c|}
\hline & & C.R. & P & $\begin{array}{c}\text { Loading } \\
\text { Factor }\end{array}$ \\
\hline KB5 & keunggulan_bersaing & & & 0.474 \\
\hline KB4 & keunggulan_bersaing & 3.451 & 0.000 & 0.458 \\
\hline KB3 & keunggulan_bersaing & 3.492 & 0.000 & 0.488 \\
\hline
\end{tabular}


Bun Norikun, Mokhamad Arwani, Mamik Indaryani

\begin{tabular}{|l|l|l|l|l|}
\hline KB2 & keunggulan_bersaing & 3.839 & 0.000 & 0.487 \\
\hline KB6 & keunggulan_bersaing & 3.982 & 0.000 & 0.766 \\
\hline KB1 & keunggulan_bersaing & 4.448 & 0.000 & 0.413 \\
\hline KP2 & kinerja_pemasaran & & & 0.551 \\
\hline KP3 & kinerja_pemasaran & 6.962 & 0.000 & 0.622 \\
\hline KP4 & kinerja_pemasaran & 5.962 & 0.000 & 0.544 \\
\hline KP1 & kinerja_pemasaran & 7.140 & 0.000 & 0.629 \\
\hline
\end{tabular}

Sumber Data: Data primer yang diolah, tahun 2018

Gambar 3 CFA Konstruk Endogen

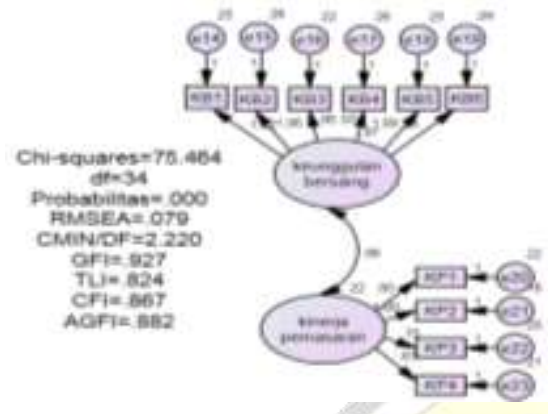

Berdasarkan tabel diatas untuk memastikan indikator telah memenuhi uji validitas kontruk, hasil dapat dilihat pada tabel 2 dan 3. Tabel menunjukkan bahwa seluruh indikator baik pada setiap variabel eksogen dan endogen dan mempunyai nilai sebagai berikut : Masing-masing indikator mempunyai nilai Critical Ratio (CR) yang lebih besar dari nilai standard error (S.E), Masing-masing indikator mempunyai nilai probabilitas $\leq 0.05$, Masingmasing indikator mempunyai nilai loading factor diatas 0.4. Hal ini dapat dipastikan bahwa semua indikator yang merefleksikan setiap variabel eksogen dan endogen tersebut merupakan satu kesatuan indikator yang diteliti.

\section{Uji Hipotesis}

Pengujian hipotesis yang diajukan dalam penelitian ini dilakukan berdasarkan nilai Critical Ratio (CR) dan nilai probabilitas dari suatu hubungan kausalitas. Dimana $\mathrm{CR}>\mathrm{t}$ tabel, nilai $\mathrm{t}_{\text {tabel }}$ digunakan tingkat signifikan $\alpha=0,05$ atau $5 \%$ dengan derajat kebebasan (degree of freedom) $\mathrm{df}=\mathrm{n}-\mathrm{k}$ atau $194-5=189$ dimana $\mathrm{n}$ adalah jumlah observasi dan $\mathrm{k}$ adalah jumlah variabel eksogen dan endogen sehingga diketahui $t_{\text {tabel }}$ sebesar 1.972 .

Tabel 4 Hasil Pengaruh Langsung

\begin{tabular}{|ccc|c|c|}
\hline Variabel Endogen & & Variabel Eksogen & C.R. & P \\
\hline KB & $<--~$ & KI & 2.518 & 0.012 \\
\hline KB & $<--~$ & OP & 2.101 & 0.036 \\
\hline KB & $<--~$ & OK & -2.010 & 0.044 \\
\hline KP & $<--~$ & OP & 3.306 & 0.000 \\
\hline KP & $<--~$ & OK & 2.188 & 0.029 \\
\hline KP & $<--~$ & KI & 2.027 & 0.043 \\
\hline KP & $<--~$ & OP & -2.777 & 0.005 \\
\hline
\end{tabular}

Sumber Data: Data primer yang diolah, tahun 2018 
bersaing (KB) memiliki pengaruh yang signifikan terhadap kinerja pemasaran KP).

Hasil hipotesis dari pengaruh tidak langsung: hipotesis 8: Menunjukkan bahwa nilai $\mathrm{CR}=3.304$ lebih besar dari nilai $t_{\text {tabel }}$ (3.304>1.972), dan probabilitas menunjukkan bahwa probabilitas $\rho=0.000$ lebih kecil dari nilai probabilitas yang disyaratkan $(\rho<0.05)$ artinya bahwa keunggulan bersaing (KB) memiliki pengaruh mediasi yang kuat antara kemampuan inovasi (KI) dengan kinerja pemasaran (KP). Hipotesis 9: Menunjukkan bahwa nilai $\mathrm{CR}=$ 2.765 lebih besar dari nilai $t_{\text {tabel }}(2.765>1.972)$, dan probabilitas menunjukkan bahwa probabilitas $\rho=0.006$ lebih kecil dari nilai probabilitas yang disyaratkan $(\rho<0.05)$ artinya bahwa keunggulan bersaing $(\mathrm{KB})$ memiliki pengaruh mediasi yang kuat antara orientasi pasar (OP) dengan kinerja pemasaran (KP). Hipotesis 10: Menunjukkan bahwa nilai $\mathrm{CR}=4.912$ lebih besar dari nilai $\mathrm{t}_{\text {tabel }}$ (4.912>1.972), dan probabilitas menunjukkan bahwa probabilitas $\rho=0.000$ lebih kecil dari nilai probabilitas yang disyaratkan $(\rho<0.05)$ artinya bahwa keunggulan bersaing (KB) memiliki pengaruh mediasi yang kuat antara orientasi kewirausahaan $(\mathrm{OK})$ dengan kinerja pemasaran (KP).

\section{KESIMPULAN DAN SARAN}

\section{Kesimpulan}

1. Pengaruh variabel eksogen yang memiliki pengaruh paling besar adalah pengaruh antara keunggulan bersaing terhadap kinerja pemasaran pada UKM kerajinan konveksi Kabupaten Kudus. Hal ini kerajinan konveksi yang ada di Kabupaten Kudus memiliki produk dengan desain kekinian dan memiliki harga yang terjangkau. Hal ini ditemukan bahwa kerajinan konveksi Kabupaten Kudus memiliki harga bervariasi dan terbilang terjangkau dari pesaing-pesang yang berasal dari luar kota seperti Bandung, Pekalongan, Solo dan lain sebagainya. Kerajinan konveksi Kabupaten Kudus diketahui bahwa mempunyai kemampuan daya meniru yang tinggi terhadap produk brand market, hal ini pada dasarnya kerajinan konveksi memiliki SDM yang handal dan mampu memberikan keunggulan setelah itu meningkatkan kinerja pemasaran. Sehingga semakin UKM kerajinan konveksi Kabupaten Kudus memiliki keunggulan bersaing pada pasar red ocean, maka akan meningkatkan kinerja pemasaran.
2. UKM kerajinan konveksi Kabupaten Kudus dengan kemampuan inovasi memberikan kontribusi terhadap keunggulan bersaing, setelah itu akan meningkatkan kinerja pemasaran. Ditemukan bahwa kerajinan konveksi fashion yang mengalami banyak inovasi, dimana desain/model selalu mengikuti trend atau mengikuti permintaan pasar. Kemampuan inovasi ditemukan bahwa kerajinan konveksi melakukan pertama: innovation dengan memperbaharu-an dari produk yang diinginkan pelanggan seperti model hijab selalu berkembang, fashion wanita yang menjadikan banyak mengalami inovasi, dan atau proses kerja menjadi lebih baik termasuk pembukuan administrasi, pengorganisasian, standar operasional prosedur (SOP). Kedua: Improvement dengan perbaikan dari produk yang sudah pernah dipasarkan (dimodifikasi, penam-bahan aksesoris, atau perbaikan model menjadi series), dan atau proses yang ada menjadi lebih baik. Inovasi produk juga menggabungkan dengan motif batik, bordir, sablon, dimana motif produk dikaitkan dengan kearifan local.

3. UKM kerajinan konveksi Kabupaten Kudus dengan orientasi pasar memberikan kontribusi terhadap keunggulan bersaing, setelah itu akan meningkatkan kinerja pemasaran. Ditemukan bahwa kerajinan konveksi Kabupaten Kudus menerapkan orientasi pelanggan, dengan wirausahawan maupun pegawai memberikan pelayanan yang baik terhadap pelanggan kecil maupun besar dan selanjutnya memberi kepuasan bagi pelanggan. Disisilain ada juga wirausahawan mempunyai new wave marketing, dimana pengusaha mempunyai gaya pemasaran modern dengan secara tidak langsung memberikan kedekatan terhadap pelanggan, selanjutkan akan memberikan kepuasan terhadap pelanggan, merasa dihargai dan tidak dibeda-bedakan antara kelas pelanggan kecil maupun besar. Orientasi kolaborasi juga memberikan dampak yang positif juga bagi wirausahawan dengan adanya kerjasama dengan penjahit-penjahit rumahan akan memberikan peningkatan dalam output produksi dan penjulanan, dan juga ada yang menyatakan bahwa kerjasama dengan pesaing juga dapat meningkatkan penjualan, hal ini beberapa konveksi mempunyai kerjasama yang baik antar pesaing, dalam penjualan kita bersaing, tetapi dalam kerjasama produksi 
kita mitra dengan tingkat professional yang tinggi.

4. UKM kerajinan konveksi Kabupaten Kudus dengan orientasi kewirausahaan memberikan kontribusi terhadap keunggulan bersaing, setelah itu akan meningkatkan kinerja pemasaran. Kerajinan konveksi Kabupaten Kudus mempunyai keahlian atau keterampilan dalam berwirausaha kerajinan konveksi dengan menghasilkan produk yang unggul, keahlian dalam memasarkan produk offline maupun online, akan tetapi belum semuanya mampu memasarkan secara online melainkan offline melalui pemesanan, pasar tradisional, dan daya informasi dari saudara, teman, dan rekomendasi orang lain. Dan kerajinan konveksi di Kabupaten Kudus, kurang berani dalam mengambil resiko terkait pengembangan usaha/produk dengan kemampuan meniru desain produk lain (brand market) atau inovasi produk maupun improvement, hal ini wirausahawan harus melihat terlebih dahulu produk tersebut laku atau tidak dipasar. Dampaknya kerajinan konveksi selalu tertinggal atau terlambat meniru dalam inovasi produk terhadap model yang kekinian.

\section{Saran}

Berdasarkan kesimpulan di atas, maka peneliti memberikan beberapa saran yang sekiranya dapat memberikan manfaat baik bagi UKM Kerajinan Konveksi Kabupaten Kudus, berikut beberapa saran:

1. Diketahui bahwa tanggapan responden pada kemampuan inovasi yang mempunyai tingkat kesetujuan rendah adalah inovasi proses, hal ini bahwa UKM kerajinan konveksi di Kabupeten Kudus sebagian besar memiliki kelamahan dalam inovasi yang mengikuti model yaitu selalu terlambat dalam proses peniruan model kekinian atau proses peniruan produk brand market. Serta inovasi proses di dalam produksi masih terbilang tidak tertata. Diharap UKM melakukan perubahan manajemen untuk meningkatkan inovasi proses dari produksi ataupun konsep desain yang secara cepat mengikuti tren. Peran pemerintah juga sangat penting didalam mendukung kemajuan UKM yaitu memberikan pelatihan dan wawasan tentang cara mengelola UKM yang sehat serta meningkatkan UKM menuju pemasaran global.

2. Diketahui bahwa tanggapan responden pada orientasi pasar yang mempunyai tingkat kesetujuan rendah adalah orientasi kolaborasi, hal ini bahwa UKM kerajinan konveksi Kabupaten Kudus ditemukan mayoritas konveksi belum mempunyai kerjasama atau kolaborasi bisnis dengan pesaing, hal ini pengusaha kerajinan konveksi belum banyak yang mempunyai paradigma horizontal yang berdasarkan bisnis modern. Perusahaan atau UKM jika ingin berkembang dalam memenuhi pasar, maka diharap perusahaan memikirkan dan mengikuti strategi bisnis yang berkembang dengan melakukan mitra atau kerjasama dengan sesame atau penjahit rumah untuk memenuhi output yang diminta pasar.

3. Variabel orientasi kewirausahaan mempunyai tanggapan responden tingkat kesetujuan yang rendah adalah pengambilan resiko, artinya bahwa wirausahawan UKM kerajinan konveksi kurang berani dalam mengambil resiko terkait pengembangan usaha/produk dengan kemampuan meniru desain produk lain (brand market) atau inovasi produk maupun improvement, hal ini wirausahawan harus melihat terlebih dahulu produk tersebut laku atau tidak dipasar. Hal ini diharap perusahaan atau wirausahawan UKM kerajinan konveksi harus mengkaji ulang dalam startegi meningkatkan atau mencipkan kemampuan dalam keberanian mengambil resiko resiko terkait pengembangan usaha/produk.

4. Variabel keunggulan bersaing mempunyai tanggapan responden tingkat kesetujuan yang rendah adalah ciri khas, artinya bahwa UKM kerajinan konveksi Kabupeten Kudus sedikit yang mempunyai ciri khas atau produk pembeda dari konveksi lainnya. Hal ini ratarata produk konveksi di kabupaten Kudus adalah sama, belum ada yang di unggulkan atau sebagai ciri khas. Hal ini diharap perusahaan atau UKM kerajinan konveksi harus mengkaji ulang dalam startegi menciptakan keunggulan bersaing dalam hal menciptakan produk yang mempunyai ciri khas tersendiri atau citra produk konveksinya (adanya gambar/motif kearifan local, logo, label, aksesoris/atribut, kualitas jahitan, dan lain sebagainya).

5. Variabel kinerja pemasaran mempunyai tanggapan responden tingkat kesetujuan yang rendah adalah pertumbuhan pelanggan, artinya bahwa UKM kerajinan konveksi ratarata memiliki pertumbuhan pelanggan tidak begitu pesat, karena banyaknya persaingan 
yang sangat kompetitif di produk kerajinan konveksi di kabupaten Kudus yang menawarkan berbagai kualitas, harga, pelayanan yang baik. Sehingga konsumen dapat memilih dengan jeli terhadap konveksi di Kudus. Hal ini diharap kerajinan konveksi lebih sensitive atau UKM mengkaji ulang tentang kebijakan pemasaran dan strategi meningkatkan pelanggan dan tetap loyal terhadap produk konveksi dengan memberikan kepuasan pelanggan, pelayanan pelanggan, kualitas produk, penetapan harga, memberikan bonus yang menarik, promosi/diskon, dan lain sebagainya.

\section{DAFTAR PUSTAKA}

Arwani, Mokhamad. 2011. Karakteristik Sumber Informasi dalam Membentuk Sikap Konsumen. Jurnal Analisis Manajemen, Vol.5 No.1, ISSN: 1411-1799, hal. 45-55, Universitas Muria Kudus.

Arwani, Mokhamad. 2012. An Analysis Of Marketing Mix Factor, Individual Factor And Environment Factor Which Effected In Selecting Islamic Bank. Prosiding Seminar \& Konferensi Nasional Manajemen Bisnis, hal.183-192, Universitas Muria Kudus.

David, W. Cravens. 2015. Pemasaran Strategis, Edisi Keempat, Jilid 1. Alih Bahasa Lina Salim. Jakarta : Erlangga.

Ferdinad, Augusty. 2013, Metode Penelitian Manajemen, Edisi IV, Universitas Diponegoro, Semarang.

Fred, R. David. 2008. Manajemen Strategis, Alih bahasa Ichan Setiyo, B. Jakarta: Salemba Empat.

Georgopoulos, George. 2011. Red ocean vs Blue Ocean Strategies. Master Bisiness Administration in Total Quality Management, University of Piraeus.

Hafni, Roswita dan Ahmad Rozali. 2016. Analisis Usaha Mikro, Kecil, Dan Menengah (UKM) Terhadap Penyerapan Tenaga Kerja Di Indonesia. Jurnal Ekonomi dan Bisnis, hal.77-96, UMSU.

Heru, Sulistyo, dan Siyamtinah. 2016. Innovation capability of SMEs through entrepreneurship, marketing capability, relational capital and empowerment. Journal Asia Pacific Management Review 21, p.196203, Sultan Agung Islamic University.

John, C. Narver, dan Stanley F. Slater. 1990. The Effect of a Market Orientation on Business Profitability. Journal of Marketing, p. 20-35, University of Washington.
K. Jin, Han, Namwoon Kim, dan Rajendra K. Srivastava. 1998. Market Orientation and Organizational Performance: Is Innovation a Missing Link?. Journal of Marketing, p.3045, Singapore Management University.

Kim, W. Chan dan Renee Mauborgne. 2011. Blue Ocean Strategy (Strategi Samudra Biru). Cetakan Kelima, Terjemahan, Jakarta : PT. Serambi Ilmu Semesta.

Kotler, Philip, and Gary Armstrong, 2008. Prinsip-prinsip Pemasaran, (Edisi 12), Jakarta: Erlangga.

Nandan, Limakrisna, dan Syahril Yoserizal. 2016. Determinants of marketing performance: empirical study at National Commercial Bank in Jakarta Indonesia. Journal SpringerPlus 5:1693, p.1-7, Universitas Persada Indonesia.

Norikun, Bun, dan Kuswardani. 2015. Analisis Faktor-Faktor Dalam Meningkatkan Kesuksesan Produk Baru Pada Kinerja Pemasaran (Studi Kasus pada Produk Telepon Seluler Polytron atau PT. Hartono Istana Teknologi). Jurnal Ekonomi Manajemen, hal.65-80. Universitas Semarang.

Sukirman. 2014. Pengembangan Kewirausahaan Melalui Peningkatan Kinerja Karyawan. Jurnal Ekonomi dan Bisnis, hal.143-162, Vol XVII No.1 ISSN 197-6471, Universitas Muria Kudus.

Sukirman, dan Mamik Indaryani. 2014. Strategi Pemberdayaan Usaha Kecil Menuju Kemandirian Usaha dengan Menerapkan Manajemen Prefesional. Jurnal Ekonomi dan Bisnis, hal 1-14, Universitas Muria Kudus.

Tri, Handayani, dan Suyanto. 2016. Hubungan Eq, Pengetahuan Kewirausahaan, Dan Hasrat Marginal Menabung, Dengan Motivasi Berwirausaha Mahasiswa Pendidikan Ekonomi. Harmoni Sosial: Jurnal Pendidikan IPS Volume 3, No 1, hal.95-104. Universitas Negeri Yogyakarta.

Widodo. 2008. Meningkatkan Kinerja Pemasaran Dengan Kriativitas Strategi. Jurnal Universitas Sultan Agung: Vol.1, No. 2, hal. 151-175.

Zehir, Cemal, Mahmut Kole, dan Hacer Yildiz. 2015. The Mediating Role of Innovation Capability on Market Orientation and Export Performance: an Implementation on SMEs in Turkey. Journal International Strategic Management Conference, Procedia - Social and Behavioral Sciences 207 (2015) p.700708. University Besiktas, Istanbul, Turkey. 
